Our Nature (2009) 7:163-167

\title{
Comparative Study on some Organic Manure Commonly Used in Aquaculture
}

\author{
D. Chakrabarty \\ Limnology Laboratory, Krishnagar Government College, Krishnagar-741101, Nadia, West Bengal, India \\ E-mail: debajyoti_chakrabarty64@rediffmail.com
}

Received: 10.09.2009, Accepted: 26.02.2009

\begin{abstract}
Assorted physical and chemical parameters were measured in glass aquaria (10 l) receiving some commonly used organic manure namely cow dung (CD), compost charged with rock phosphate (CR), vermin-compost charged with rock phosphate (VCR), horse dung (HD) and farm yard manure (FYM). There was no significant difference in the moisture content of the manures tested. The values of $\mathrm{pH}$, conductance, TDS, $\mathrm{PO}_{4}-\mathrm{P}, \mathrm{NH}_{3}-\mathrm{N}$ was highest in the VCR treatment indicating a better manurial value for VCR than others. The size of fibers of VCR was significantly $(\mathrm{P}>0.05)$ lower in size when compared with other manures tested. There was almost no difference in fiber content of the manures tested except VCR where it was significantly low $(p<0.05)$ than other four. The different organic manures used can be graded in the following descending order in manurial value as direct application manure: VCR $\left(\mathrm{T}_{3}\right)$ $>\mathrm{CD}\left(\mathrm{T}_{1}\right)>\mathrm{CR}\left(\mathrm{T}_{2}\right)>\mathrm{HD}\left(\mathrm{T}_{4}\right)>\mathrm{FYM}\left(\mathrm{T}_{5}\right)$. The values of total suspended solids (TSS) imparted by the manures showed significant differences $(\mathrm{P}>0.05)$ among various treatments and was in the following descending order: $\mathrm{HD}\left(\mathrm{T}_{4}\right)>\mathrm{CD}\left(\mathrm{T}_{1}\right)>\mathrm{CR}\left(\mathrm{T}_{2}\right)>\mathrm{FYM}\left(\mathrm{T}_{5}\right)>$ $\operatorname{VCR}\left(\mathrm{T}_{3}\right)$. This indicates that the application of (VCR) will pass on less fiber garbage to aquatic body.
\end{abstract}

Key words: Limnology, aquaculture, vermi-compost, organic manure, rock phosphate

\section{Introduction}

The purpose of pond manuring is primarily to provide adequate amounts of essentials nutrients for phytoplankton production (Wunder, 1949; Edwards, 1980; Jhingran, 1997). Manuring is widely practiced in fishponds for natural fish production as it is important to sustainable aquaculture and to reduce expenditure on costly feeds and fertilizers which form more than $50 \%$ of the total input cost (Edwards, 1980; Pillay, 1995; Omoyinmi et al., 2005). Wide variety of organic manures such as grass, leaves, sewage water, livestock manure, industrial wastes, night soil, compost, farm yard manure, vermicompost, dried blood meal have been used (Schroeder, 1980; Dhawan,
1989; Jhingran, 1997; Chakrabarty et al., 2009) to improve fish production.

The major disadvantage of application of organic manures is that it contains very low amount of available phosphorus, for that a huge quantity of organic manures is required to apply for improvement in production (Hickling, 1962; Schroeder, 1980). The amount of available phosphorus is high in chemically processed fertilizer, but it renders pollution from its production to use (Rand, 2003). So, organic manures should be improved in their available phosphorus content before application in the aquatic system. The phosphate rock excavated from mine and ground to 100- 
mesh size and used as rock phate contains insoluble tricalcium phosphate (Chakrabarty, 1994). The phosphate rock if treated in proper way (weathering, composting etc.) may be used to improve the soluble-P content of organic manure.

The problem of application of organic manures in an aquatic body is that it leaves a blanket of fibers over the sediment, which blocks the succession of chemical response in the sediment water interface (Jhingran, 1997; Rand, 2003; Chakrabarty, 2008). The chain of chemical reaction in the sediment water interface helps in releasing the sediment bound macro and micronutrient (Tacon, 1987; Pillay, 1995; Chakrabarty et al., 2007). The cellulose blanket also increases deoxygenation of water (Probst, 1950; Hickling 1962). Naturally the application of regular and huge quantity of cellulose containing organic manures renders a productive aquatic body into unproductive and useless (Smith and Swingle, 1939; Silva and Anderson, 1995). The present trial was undertaken to study the size and percentage of the fibers, improvement of available-p in organic manure mixing rock phosphate and also to assess the water quality parameters in aquariums receiving five organic manures, namely cow dung (CD), compost charged with rock phosphate (CR), vermicompost charged with rock phosphate (VCR), horse dung (HD) and farm yard manure (FYM).

\section{Materials and methods}

The present trial was conducted in limnology laboratory of Krishnagar Government College during May-July (Temp. $34^{\circ} \mathrm{C}$ ). Fifteen glass aquaria (capacity 10 liters) were treated with five different types of organic manures namely, cow dung $(\mathrm{CD})$, compost charged with rock phosphate (CR), vermicompost charged with rock phosphate (VCR), horse dung (HD) and farm yard manure (FYM). It is necessary to mention that rock phosphates is an igneous phosphate rock in the form of insoluble tricalcium phosphate excavated from mine and ground to 100 mesh size and marketed as rock phosphate (PPCL, 1987). The purulia rockphosphate (an indigenous variety of rock phosphate of West Bengal, India) was used here. In this trial an effort has been taken to improve the available-P through vermicomposting.

\section{Preparation of manure}

1. Cow dung $\left(\mathrm{CD}=\mathrm{T}_{1}\right)$ : Freshly collected faecal matter from adult Bovis indicus, used in the experiment.

2. Compost charged with rock phosphate $\left(\mathrm{CR}=\mathrm{T}_{2}\right)$ : Fresh Eichornia crassipes and Cowdung were collected from nearby area chopped in small pieces are and mixed Purulia rock phosphate in the ratio of 1:1:0.05 and composted for 75 days in an earthen vat.

3. Vermicompost charged with rock phosphate $\left(\mathrm{VCR}=\mathrm{T}_{3}\right)$ : Cowdung, Eichornia crassipes and Purulia rock phosphate was mixed in 1:1:0.05 ratio for and left for partial decomposition for 45 days then earthworm (Eudrillus euginae) were allowed to grow in that substrate, the finished vermicompost was collected after 30 days.

4. Horse dung $\left(\mathrm{HD}=\mathrm{T}_{4}\right)$ : Freshly collected faecal matter from adult Equs equs, used in the experiment.

5. Farmyard manure $\left(\mathrm{FYM}=\mathrm{T}_{5}\right)$ : The manure was collected from a private farm nearby.

Application of manures and estimation of various parameters 


\section{Chakrabarty / Our Nature (2009) 7: 163-167}

The moisture content of the above mentioned materials were analyzed using a standard moisture meter. Then the materials were applied in equal amount in dry weight basis to glass aquarium containing 10L tap water. The materials were thoroughly mixed with a glass rod. Every set was allowed to settle for 24 hours. The sample from settled materials (fibers) were taken out with the help of a pipette, fibers such collected dried in air and the lengths were measured in a microscope using ocular micrometer. A definite amount (50g dry weight) from each testing sample was dissolved separately in distilled water $(500 \mathrm{ml})$, mixed thoroughly and the whole water mixed manure was filtered through a sieve (pore size10 $\mu$ ) The filtrate was collected and dried in a hot air oven for 24 hours in $100^{\circ} \mathrm{C}$ and then weighted in a digital balance. The final weight was subtracted from the initial weight to get the fiber content. The values of $\mathrm{pH}$, conductance, total suspended solids (TSS), total dissolved solids (TDS), $\mathrm{PO}_{4}-\mathrm{P}$, $\mathrm{NH}_{3}-\mathrm{N}$ of the water of the aquarium were measured following Standard Methods (2005) and with standard equipments.

\section{Statistical analysis}

The data obtained from the various treatments was evaluated using one-way analysis of variance (one way). The SPSS software was used to analyze the data.

\section{Results and discussion}

The interpretation of the Table 1 shows that the lowest moisture content was found in VCR followed by FYM, CR, HD and CD respectively. There was no significant difference in the moisture content of the manures tested. The values of $\mathrm{pH}$, conductance, TDS, $\mathrm{PO}_{4}-\mathrm{P}, \quad \mathrm{NH}_{3}-\mathrm{N}$ was highest in the $\left(\mathrm{T}_{3}\right)$ treatment indicating a better manurial value for VCR than others. However, there was no significant differences $(\mathrm{P}>0.05)$ in the values of $\mathrm{pH}$, conductance, TDS, $\mathrm{NH}_{3}-\mathrm{N}$ concentration, but a significant difference was observed in the concentration of $\mathrm{PO}_{4}-\mathrm{P}$. This was probably due to the superior microbial action in the gut of the earthworm during the digestion process (Ramu, 2001; Dynes, 2003; Omoyinmi et al., 2005; Verma and Prasad, 2005) that helped in liberating phosphorus from bound form in the rations of the earthworms. The same treatment combination (CR) which was allowed to decompose without earthworms failed to release phosphorus. This is also worth mentioning that, due to the utilization of iron from the substrate by the earthworms for the production of their serum hemoglobin, iron bound phosphate was released from the substrates in turn. Among the various organic manures tested the percentage of fiber was lowest $(25 \%)$ in vermicompost followed by cow dung $(60 \%)$; horse dung $(63 \%)$; farmyard manure $(64 \%)$; compost $(65 \%)$. There was almost no difference in fiber content of the manures tested except vermicompost where it was significantly low $(\mathrm{p}<0.05)$ than other four (Tab.1).

The length measurement of fiber present in the manure (Tab.1) demonstrated highest value in the FYM $\left(\mathrm{T}_{5}\right)$ followed by CR $\left(\mathrm{T}_{2}\right)$. The length of fiber was moderate in the faecal matters of $\mathrm{CD}\left(\mathrm{T}_{1}\right)$ and $\mathrm{HD}\left(\mathrm{T}_{4}\right)$. Lowest fiber size was observed in VCR $\left(\mathrm{T}_{3}\right)$. Lowest values of fiber size were encountered in the VCR due to the intensive grinding of the organic substances in the gut of the earthworms during digestion process (Sinha et al., 2002; Sogbesan and Ugwumba, 2006). Smallest sizes of fibers indicate that as organic manure the VCR 
D. Chakrabarty / Our Nature (2009) 7: 163-167

Table 1. Physico-chemical characteristics of various organic manures tested in laboratory aquaria.

\begin{tabular}{|c|c|c|c|c|c|c|c|c|c|}
\hline Manures & $\begin{array}{c}\text { Fibers } \\
(\%)\end{array}$ & $\begin{array}{c}\text { Moisture } \\
(\%)\end{array}$ & $\begin{array}{l}\text { Length of } \\
\text { fibers }(\mu)\end{array}$ & $\overline{\mathrm{pH}}$ & $\begin{array}{c}\text { Conductance } \\
\left(\mu \mathrm{mhos} \mathrm{cm}^{-1}\right)\end{array}$ & $\begin{array}{l}\text { TSS } \\
\text { mgl }^{-1}\end{array}$ & $\begin{array}{l}\text { TDS } \\
\text { mgl }^{-1}\end{array}$ & $\mathrm{PO}_{4}-\mathrm{P} \mathrm{mgl}{ }^{-1}$ & $\begin{array}{c}\mathrm{NH}_{3}-\mathrm{N} \\
\mathrm{mgl}^{-1}\end{array}$ \\
\hline$\overline{\mathrm{CD}\left(\mathrm{T}_{1}\right)}$ & 60 & 82 & $60-125$ & $7.4 \pm .05$ & $295 \pm 15$ & $1.3 \pm 0.03$ & $273 \pm 12$ & $0 . .08 \pm 0.02$ & $0.08 \pm 0.01$ \\
\hline $\mathrm{CR}\left(\mathrm{T}_{2}\right)$ & 65 & 78 & $90-250$ & $7.2 \pm .06$ & $268 \pm 13$ & $1.2 \pm 0.03$ & $240 \pm 13$ & $0.08 \pm 0.01$ & $0.07 \pm 0.01$ \\
\hline $\operatorname{VCR}\left(\mathrm{T}_{3}\right)$ & $25 \bullet$ & 75 & $10-15 \bullet \bullet$ & $7.4 \pm .05$ & $323 \pm 14$ & $0.2 \pm 0.005 \bullet \bullet$ & $315 \pm 15$ & $0.16 \pm 0.02 \bullet \bullet$ & $0.10 \pm 0.02$ \\
\hline $\mathrm{HD}\left(\mathrm{T}_{4}\right)$ & 63 & 80 & $80-135$ & $7.3 \pm .04$ & $296 \pm 13$ & $1.4 \pm 0.04$ & $283 \pm 14$ & $0.09 \pm 0.02$ & $0.10 \pm 0.02$ \\
\hline $\mathrm{FYM}\left(\mathrm{T}_{5}\right)$ & 64 & 76 & $90-300$ & $7.2 \pm .02$ & $278 \pm 11$ & $1.1 \pm 0.03$ & $280 \pm 15$ & $0.06 \pm 0.02$ & $0.08 \pm 0.01$ \\
\hline $\begin{array}{l}\text { (ANOVA } \\
\text { oneway) }\end{array}$ & $\mathrm{P}<0.05$ & ns & $\mathrm{P}<0.001$ & ns & ns & $\mathrm{P}<0.001$ & ns & $\mathrm{P}<0.001$ & ns \\
\hline
\end{tabular}

Level of significance: $\mathrm{ns}=$ not significant; $\bullet=\mathrm{P}<0.05, \bullet=\mathrm{P}<0.001$

would not pose any threat of spreading the blanket of fiber over the sediment.

The values of total suspended solids (TSS) showed significant differences $(\mathrm{P}>0.05)$ among various treatments and was in the following descending order; $\mathrm{HD}\left(\mathrm{T}_{4}\right)$ $>\mathrm{CD}\left(\mathrm{T}_{1}\right)>\mathrm{CR}\left(\mathrm{T}_{2}\right)>\mathrm{FYM}\left(\mathrm{T}_{5}\right)>\mathrm{VCR}$ $\left(\mathrm{T}_{3}\right)$. This indicates that application of vermicompost charged with rock phosphate (VCR) will impart less fiber garbage to aquatic body. However, considering all the qualities different organic manures tested here can be graded in the following descending order in manurial value as direct application manure: VCR $\left(\mathrm{T}_{3}\right)>\mathrm{CD}\left(\mathrm{T}_{1}\right)>$ $\mathrm{CR}\left(\mathrm{T}_{2}\right)>\mathrm{HD}\left(\mathrm{T}_{4}\right)>\operatorname{FYM}\left(\mathrm{T}_{5}\right)$.

\section{References}

Chakrabarty, D. 1994 Application of phosphate rock in carp culture: Responses of phosphorus in sediments. University of kalyani. Kalyani, WB, India. Ph.D. thesis.

Chakrabarty, D. 2008. Vermicompost and organic Pisciculture. Akshay Krishi Vikash (Publisher), West Bengal, India. pp. 1-16.

Chakrabarty, D., S.K. Das and M.K. Das 2007. Modeling of energy transformations in fertilized tropical fish ponds. Lakes and Reservoirs: Research and Management 12: 295-301.

Chakrabarty, D., S.K. Das and M.K. Das 2009. Relative efficiency of vermicompost as direct application manure in pisciculture. Paddy water Environ. 7: 27-32.

Dhawan A. 1989. Impact of organic manure and supplementary diet on plankton production and fish growth and fecundity of an Indian major carp, Cirrhina mrigala (Ham.) in fishponds. Biol. Wastes 29: 289-297.

Dynes, R.A. 2003. Earthworms-Technology information to enable the development of earthworm production. Rural Institute Research Development Corporation Publication No. 03/085, 23 September, 2003. pp. 1-3.

Edwards, P. 1980. A review of recycling wastes into fish, with emphasis on the tropics, Aquaculture 21: 261-279.

Hickling, C.F. 1962. Fish culture. Faber and Faber, London, UK.

Jhingran, V.G. 1997. Fish and Fisheries of India. Hindustan Publishing Corporation, New Delhi, India.

Omoyinmi, G.A.K., S.O. Fagade and A.A. Adebisi 2005. Assessment of different organic substrates in the laboratory-culture of some live food organisms. The Zoologist 3: 105-111.

Pillay, T.V.R. 1995. Aquaculture- Principles and practices. Fishing News Books, Cambridge, England.

Probst, E. 1950. Teichdungung Die Bedeutung des phosphors. Allg. Fisch. Zig. 89: 191-194.

Ramu, K. 2001. Worm Culture's important role. Fish Farmer 15: 31.

Rand, M.G. 2003. Aquatic Toxicology. $2^{\text {nd }}$ Edition. Taylor and Francis, London.

Schroeder, G.L. 1980. Fish farming in manure loaded ponds. In Integrated agriculture/aquaculture 
D. Chakrabarty / Our Nature (2009) 7: 163-167

farming systems (Eds. R.S.V. Pullin and $\mathrm{H}$. Shahadh). ICLARM, Conf. Proc. 4. pp 73-86.

Silva, S.S. and T.A. Anderson 1995. Fish nutrition in aquaculture. Chapman and Hall Publ., New Delhi, India.

Sinha, R.K., S. Heart, S. Agarwal, R. Asadi and E. Carretero 2002. Vermiculture and Waste management: study of action of earthworms Eisenia foetida, Eudrilus euginae and perionyx excavatus on biodegradation of some community wastes in India and Australia. The Environmentalist 22: 261-268.

Smith, E.V. and H.S. Swingle 1939. The relation between plankton production and fish production in ponds. Trans. Am. Fish. Soc. 68: 310-315.

Sogbesan, O.A and A.A.A. Ugwumba 2006. Effect of different Substrates on Growth and Productivity of Nigeria Semi-Arid Zone Earthworm (Hyperiodrilus euryaulos, Clausen 1842) (Oligochaeta: Eudrilinae). World Journal of Zoology 1(2): 103112.

Tacon, A.G.J. 1987. The Nutrition and feeding of farmed fish and shrimps- A training Sources and Composition. Project GCP/RLA/075/ITA.

Verma, P. and A. Prasad 2005. Vermicomposting: A potential Technology for solid waste management. 4(5): 33-35.

Wunder, W. 1949. Fortschrittliche Karpfenteichwirtschaft (progressive pond culture of carp): 386 Schweitzer bart 'che Verlagbuch handlung, Erwin Nagele Stuttgart. 